\title{
Severity Criteria
}

National Cancer Institute

\section{Source}

National Cancer Institute. Severity Criteria. NCI Thesaurus. Code C117962.

A standard from which a judgment concerning an event severity can be established. 